\title{
Role of intra-abdominal pressure in the outcomes of perforation peritonitis: A prospective observational study
}

\author{
Pritesh Kumar N(D), Lovenish Bains(D), Pawan Lal(D), Anurag Mishra(D), Mohd Yasir Beg(D), Haraesh Maranna(iD) \\ Department of Surgery, Maulana Azad Medical College, New Delhi, India
}

\begin{abstract}
Objective: Intra-abdominal pressure (IAP) has been investigated for its role in causing morbidity and mortality, with various studies showing different degrees of correlation. There remains paucity of literature on this subject, applied to patients of perforation peritonitis, especially in the Indian subcontinent.

Material and Methods: It is a prospective observational study involving 40 patients of perforation peritonitis undergoing exploratory laparotomy. IAP was measured as per WSACS (World Society of Abdominal Compartment Syndrome) guidelines. APACHE II (Acute Physiology And Chronic Health Evaluation- II) and SOFA (Sequential Organ Failure Assessment) were calculated. Data was collected regarding occurrence of prolonged ileus, burst abdomen, duration of hospital stay, 30 day mortality, and was statistically analyzed to correlate with IAP.

Results: At admission, mean IAP was $13.37 \mathrm{mmHg}$, and the incidence of IAH was $65 \%$. IAH was seen in $17.9 \%$ and $7.6 \%$ at $24 \mathrm{~h}$ and $48 \mathrm{~h}$ post-operatively Incidence of prolonged ileus and burst abdomen were $7.7 \%$ and $22.5 \%$ respectively. Mortality rate was $17.5 \%$. Mean duration of hospital stay was 13.45 days. Post-operative IAP correlated with mortality ( $p$ : 0.014$)$ and post-operative SOFA score ( $p<0.05)$. Statistically significant correlation was also seen with the occurrence of prolonged ileus ( $p$ : 0.006). IAP did not significantly correlate with APACHE II score, occurrence of burst abdomen, and duration of hospital stay.

Conclusion: Rise in IAP correlates with deterioration of SOFA score, and also with the occurrence of prolonged ileus. IAP is also a predictor of mortality. IAP measured post-operatively ( 24 and 48 hours) had a better correlation with these outcomes than the value measured at admission. No statistically significant correlation of IAP with the occurrence of burst abdomen and duration of hospital stay could be found, which warrants further studies with a larger population.
\end{abstract}

Keywords: Perforation peritonitis, intra-abdominal pressure, intra-abdominal hypertension, abdominal compartment syndrome

Cite this article as: Kumar NP, Bains L, Lal P, Mishra A, Beg MY, Maranna $\mathrm{H}$. Role of intra-abdominal pressure in the outcomes of perforation peritonitis: A prospective observational study. Turk J Surg 2021; 37 (3): 253-259.

\section{Corresponding Author}

Lovenish Bains

E-mail: lovenishbains@gmail.com

Received: 06.10.2020

Accepted: 19.04 .202

Available Online Date: 28.09 .2021

() Copyright 2021 by Turkish Surgical Society Available online at www.turkjsurg.com

DOI: $10.47717 /$ turkjsurg.2021.4945

\section{INTRODUCTION}

Perforation peritonitis is a common surgical emergency associated with morbidity as well as mortality, most of which is attributed to sepsis and multi-organ dysfunction syndrome. An important, yet often unrecognized factor contributing to the exacerbation of adverse outcomes in these patients is the increase in intra-abdominal pressure (IAP) which may be due to spillage of bowel contents, peritoneal inflammation causing third-space fluid accumulation, bowel edema, adynamic ileus and abdominal wall spasm. The resultant intra-abdominal hypertension may be seen in as many as $66 \%$ of patients of perforation peritonitis (1).

Increased IAP adversely impacts the functioning of various organ systems- respiratory, cardiac, renal, gastro-intestinal, which inevitably leads to increase morbidity and mortality (2).The presence of IAH in critically ill patients has been recognized as an independent predictor of mortality (3).

Much of western literature on IAP/IAH/ACS has focused on the critically ill, comprising patients of trauma, burns, medical as well as surgical illnesses admitted in the intensive care units (ICU). Although the number of published studies in patients of acute surgical illnesses is steadily increasing, there is still a paucity of literature on IAP in patients of perforation peritonitis, especially in the Indian subcontinent (4). We conducted a study to evaluate the role of IAP and correlate it with organ dys- 
function, prolonged ileus, burst abdomen, duration of hospital stay and 30-day all-cause mortality.

\section{MATERIAL and METHODS}

This was a prospective observational study conducted in a single unit in the Department of Surgery at a tertiary care hospital in New Delhi, India, over a period of one year. The study was approved by the institutional ethics committee. Study population consisted of patients of perforation peritonitis. Inclusion criteria were age $\geq 18$ years, and patients undergoing exploratory laparotomy. Abdominal drain placement prior to laparotomy, pregnancy, previous abdomino-pelvic surgery and failure of urethral catheterization were exclusion criteria. Using the general formula for sample size calculation by z-statistics, a sample size of 246 was estimated. However, a sample size of 40 was taken for convenience (Figure 1). Written informed consent was taken from the patients or their legal representatives. Primary end point of the study was to determine the value of IAP in patients of perforation peritonitis. Secondary end points were organ dysfunction (SOFA score), occurrence of prolonged ileus, burst abdomen, duration of hospital stay and 30 day all-cause mortality.

Relevant data were retrieved from the clinical notes that included patient particulars, clinical examination findings (including vitals), and reports of lab investigations. APACHE II and SOFA scores were calculated at the time of admission $(5,6)$. Intra-abdominal pressure was indirectly determined by measuring urinary bladder pressure with a Foley's catheter according to the World Society of Abdominal Compartment Syndrome (WSACS) guidelines using saline manometry (7). A conversion factor of 1.36 was used to convert IAP values in $\mathrm{cm} \mathrm{H}_{2} \mathrm{O}$ to $\mathrm{mmHg}$.

Pre-operatively, IAP measurements were taken at the time of admission, just before induction of general anesthesia (GA), and soon after induction of GA, but before laparotomy. Post-operatively IAP was measured and SOFA score was calculated at 24 and 48 hours. Occurrence of burst abdomen, occurrence of prolonged ileus, and duration of hospital stay were noted. Patients were followed-up until 30 days postoperatively for mortality data.

Intra-abdominal hypertension (IAH) was defined by a sustained IAP of $12 \mathrm{mmHg}$ or higher. Prolonged ileus was defined as the absence of bowel sounds and a 24 hour-gastric output (via Ryle's tube) of more than $500 \mathrm{ml}$ even after 3 days of laparotomy. Burst abdomen was defined as post-operative separation of abdominal musculo-aponeurotic layers. Duration of hospital stay was measured from the day of admission until the day of discharge from the hospital. Mortality included deaths occurring within 30 days of laparotomy irrespective of the cause.

\section{Statistical Analysis}

The collected data was entered in MS-Excel and analyzed by SPSS version 25.0. For continuous variables, mean (with standard deviation) was reported. For categorical variables, proportions and percentages were reported. For quantitative data, Student t-test was used. Pearson's correlation co-efficient was used to correlate intra-abdominal pressure with the outcomes. P-values $<0.05$ was taken for statistical significance.

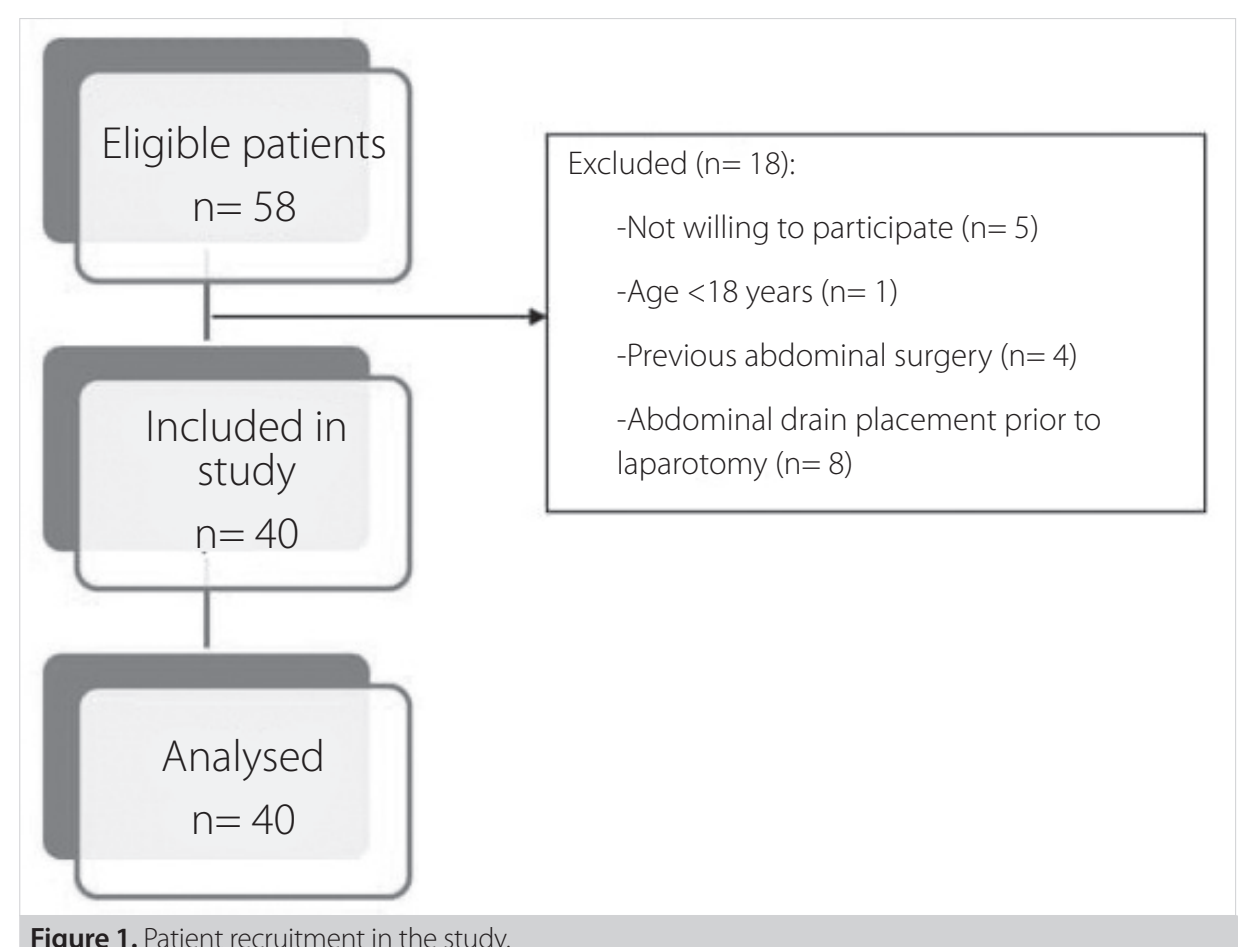

Figure 1. Patient recruitment in the study. 
Table 1. Master table (*Values expressed as mean \pm SD (Range)

\section{$\mathrm{n}=\mathbf{4 0}$}

\begin{tabular}{|c|c|}
\hline 1. Mean age(years) & $37.375(18-70)$ \\
\hline 2. Sex (M:F) & $24: 16$ \\
\hline $\begin{array}{l}\text { 3. Etiology of perforation perito- } \\
\text { nitis }\end{array}$ & $\begin{array}{l}\text { Acid peptic disease (47.5\%) } \\
\text { Tuberculosis (22.5\%) } \\
\text { Enteric fever (10\%) } \\
\text { Blunt trauma abdomen (7.5\%) } \\
\text { Acute mesenteric ischemia (5\%) } \\
\text { Acute appendicitis (2.5\%) } \\
\text { Crohn's disease (2.5\%) } \\
\text { Penetrating trauma (2.5\%) }\end{array}$ \\
\hline 4. Mean IAP in $\mathrm{mmHg}$ & $\begin{array}{l}\text { At admission: } 13.73 \pm 4.30 \\
\text { Pre-induction: } 13.44 \pm 4.90 \\
\text { Post-induction: } 13.31 \pm 4.28 \\
24 \text { h post-op: } 9.37 \pm 2.97 \\
48 \text { h post-op: } 8.16 \pm 2.93\end{array}$ \\
\hline 5. Mean APACHE II score & $7.55 \pm 4.96(0-21)$ \\
\hline 6. Mean SOFA score & $\begin{array}{l}\text { At admission: } 2.25 \pm 1.65(0-6) \\
24 \text { h post-op: } 2.82 \pm 2.98(0-13) \\
48 \text { h post-op: } 2.82 \pm 3.20(0-13)\end{array}$ \\
\hline 7. Occurrence of prolonged ileus & $7.7 \%(n=3)$ \\
\hline 8. Occurrence of burst abdomen & $22.5 \%(n=9)$ \\
\hline 9. Mortality & $17.5 \%(n=7)$ \\
\hline 10. Duration of hospital stay $(n=33)$ & $13.45 \pm 10.28$ days (Median 9 days) \\
\hline
\end{tabular}

\section{RESULTS}

Mean intra-abdominal pressure at admission was $13.73 \mathrm{mmHg}$ while mean post-operative IAP was $8.77 \mathrm{mmHg}$. Incidence of IAH at admission was 65\% (grade I IAH 37.5\%, grade II IAH 22.5\%, grade III and IV IAH 2.5\% each). One patient died within 24 hours of surgery, due to which post-operative IAP values at 24 and 48 hours were obtained for 39 patients only. Post-laparotomy, normal IAP was seen in $82 \%$ and $92 \%$ after 24 and 48 hours of surgery, respectively. Grade I IAH was present in 15.4\% patients after 24 hours of surgery, and $5.1 \%$ after 48 hours. Grade II IAH was seen in $2.5 \%$ patients after 24 as well as 48 hours. None of the patients had grade III or IV IAH post-operatively. Other relevant values have been shown in Table 1.

Pearson correlation co-efficient was calculated to determine the correlation between IAP measured at various time periods with the prognostic scores calculated at specified time intervals (Table 2). At Pearson co-efficient level of 0.05, the IAP measured after 24 hours of surgery correlated with SOFA score measured after 48 hours, which was statistically significant ( $p$ value 0.021 ). At the level of 0.01 , statistically significant correlation was found between IAP measured after 24 hours, as well as after 48 hours of surgery (Table 3). Linear regression analysis using scatter plots between IAP and corresponding SOFA score revealed a small positive correlation between the two variables, which progressively increased from pre-operative to post-operative period (Figure 2).

Table 2. Distribution of IAP in patients of perforation peritonitis at specified time intervals

\begin{tabular}{|l|c|c|c|c|c|}
\hline IAP in $\mathbf{m m H g}(\mathbf{I A H}$ Grade) & $\mathbf{< 1 2}$ (no IAH) & $\mathbf{1 2 - 1 5}$ (Grade I) & $\mathbf{1 6 - 2 0}$ (Grade II) & $\mathbf{2 1 - 2 5}$ (Grade III) & $\mathbf{> 2 5}$ (Grade IV) \\
\hline At admission $(\mathrm{n}=40)$ & $35 \%$ & $37.5 \%$ & $22.5 \%$ & $2.5 \%$ & $2.5 \%$ \\
\hline Before induction of GA $(\mathrm{n}=40)$ & $35 \%$ & $37.5 \%$ & $22.5 \%$ & $2.5 \%$ & $2.5 \%$ \\
\hline After induction of GA $(n=40)$ & $37.5 \%$ & $30 \%$ & $30 \%$ & 0 & 0 \\
\hline 24 h post-surgery $(n=39)$ & $82.05 \%$ & $15.4 \%$ & $2.5 \%$ & 0 & 0 \\
\hline 48 h post-surgery $(n=39)$ & $92.3 \%$ & $5.1 \%$ & $2.5 \%$ & & 0 \\
\hline
\end{tabular}

Table 3. Correlation between intra-abdominal pressure (IAP) and prognostic scores

\begin{tabular}{|c|c|c|c|c|c|c|c|c|}
\hline & \multicolumn{2}{|c|}{$\begin{array}{l}\text { APACHE II at } \\
\text { presentation }\end{array}$} & \multicolumn{2}{|c|}{$\begin{array}{l}\text { SOFA score at } \\
\text { presentation }\end{array}$} & \multicolumn{2}{|c|}{$\begin{array}{l}\text { SOFA score after } 24 \\
\text { hours of surgery }\end{array}$} & \multicolumn{2}{|c|}{$\begin{array}{c}\text { SOFA score after } 48 \\
\text { hours of surgery }\end{array}$} \\
\hline & r & $\mathrm{p}$ & $r$ & $p$ & r & $\mathrm{p}$ & r & $\mathrm{p}$ \\
\hline IAP at presentation & 0.250 & 0.120 & 0.258 & 0.108 & 0.193 & 0.240 & 0.151 & 0.359 \\
\hline IAP before induction of GA & 0.252 & 0.117 & 0.230 & 0.154 & 0.158 & 0.336 & 0.115 & 0.486 \\
\hline IAP after induction of GA & 0.141 & 0.384 & 0.182 & 0.260 & 0.025 & 0.880 & 0.005 & 0.978 \\
\hline IAP after 24 hours of surgery & 0.152 & 0.355 & 0.133 & 0.420 & 0.310 & 0.055 & $0.368^{*}$ & 0.021 \\
\hline IAP after 48 hours of surgery & 0.190 & 0.246 & 0.198 & 0.227 & $0.482^{* *}$ & 0.002 & $0.565 * *$ & $<0.001$ \\
\hline
\end{tabular}




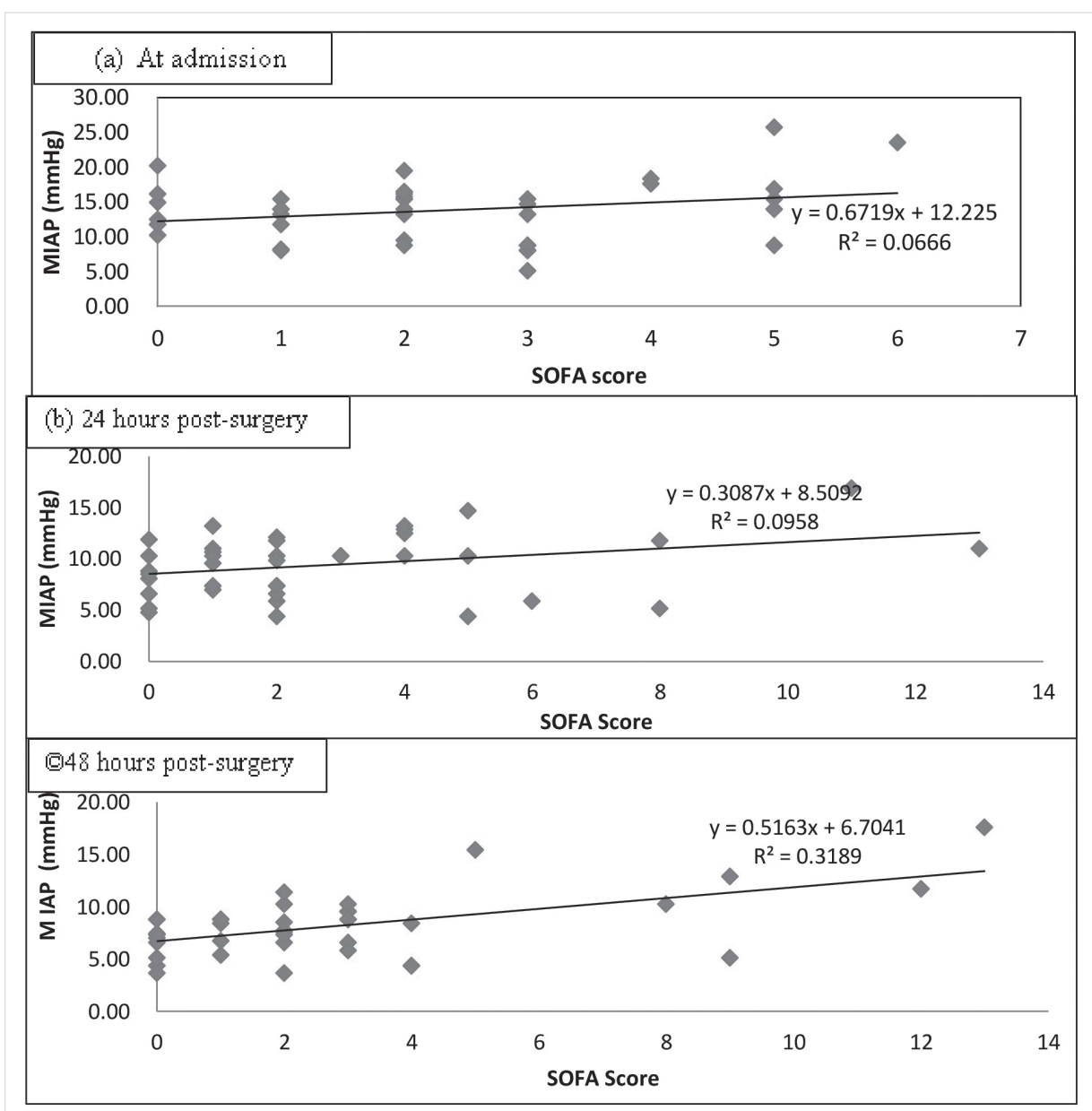

Figure 2. Scatter plots between IAP and SOFA score.

Table 4. Correlation between intra-abdominal pressure (IAP) and outcomes

\begin{tabular}{|c|c|c|c|}
\hline Outcome & Value & Correlation with IAP (t-value)* & $\mathbf{p}$ \\
\hline Mortality rate & $17.5 \%(n=7)$ & 2.587 & 0.014 \\
\hline Incidence of prolonged ileus & $7.7 \%(n=3)$ & 2.948 & 0.006 \\
\hline Incidence of burst abdomen & $22.5 \%(n=9)$ & 1.087 & 0.284 \\
\hline Duration of hospital stay (in survivors) & 13.45 days $(n=33)$ & -0.198 & 0.226 \\
\hline
\end{tabular}

Mortality rate was $17.5 \%$, with majority of deaths occurring in the age group of 31-40 years (42.5\%). IAP measured at 48 hours post-operatively correlated with mortality ( $p$ value 0.014). There was a positive correlation with IAP measured at 24 hours, but it was not statistically significant. Prolonged ileus was seen in $7.7 \%$ of the patients, and in them, the IAP measured at all five time periods correlated significantly (highest correlation seen with IAP just before induction of GA). Burst abdomen was seen in $22.5 \%$ of the cases, but its occurrence did not correlate significantly with IAP. Mean duration of hospital stay among the survivors was 13.45 days, and was not associated with the IAP.

\section{DISCUSSION}

Intra-abdominal hypertension (IAH) is defined as the sustained or repeated pathologic elevation of IAP >12 mmHg. Abdominal compartment syndrome is defined as a sustained increase in IAP > $20 \mathrm{mmHg}$ that is associated with new organ dysfunction (8). Rise of IAP in perforation peritonitis is contributed by a number of factors. Site of perforation facilitates the escape of bowel gases and luminal contents. The spillage of these contents incites an inflammatory process that may involve the entire peritoneal cavity. A number of chemical mediators act on the large available surface area of the peritoneum and result in 
third-space accumulation of fluid which can be as high as 4 to 6 liters (9). Edema of the abdominal contents increases their volume. In addition, adynamic ileus ensues that further distends the gut with fluid and swallowed air. Fluid secretion into the gut is markedly enhanced, whilst absorption of the fluid from the gut is markedly impaired. There is therefore, sequestration of a large volume of fluid within the lumen of the gut. Marked peritoneal inflammation is often associated with guarding. This spasm of the abdominal musculature impedes abdominal wall expansion, thereby contributing to the increase in IAP.

In our study, mean IAP in patients of perforation peritonitis, measured at admission was $13.73 \pm 4.30 \mathrm{mmHg}$. Following this measurement, Ryle's tube insertion was done and patients were resuscitated to be taken up for surgery. The patients were then shifted inside the operating room where IAP was measured just prior to induction of GA. Mean value was $13.44 \pm 4.90 \mathrm{mmHg}$, which was slightly less than the IAP at admission. This can be explained by gastric decompression following Ryle's tube insertion. Post-induction, but prior to laparotomy, the mean value was $13.31 \pm 4.28 \mathrm{mmHg}$. This further fall can be explained by relaxation of the abdominal muscles caused by muscle relaxants that are used as a part of general anesthesia. In fact, neuromuscular blockade is one of the proposed non-operative methods of management of IAH/ACS in non-surgical patients (10). It can be seen in Table 2 that there is a slight increase in the incidence of grade II IAH after induction of general anesthesia. This paradox can be attributed to the effect of positive airway pressure during which the diaphragm is pushed down, thereby marginally increasing the IAP. The next measurements of IAP were taken at 24 and 48 hours post-operatively. Mean values were $9.63 \pm 2.96$ and $8.44 \pm 2.9 \mathrm{mmHg}$, respectively, both falling in the range of normal IAP. Overall, mean post-operative IAP was $8.77 \pm 3.01$. Incidence of IAH at admission in our study was $65 \%$. Post-operatively, IAH was seen in only $17.9 \%$ and $7.6 \%$ respectively at 24 and 48 hours respectively.

Mean IAP in the cases studied by Sugrue et al. (11) before and after decompression is $16.6 \pm 9.4 \mathrm{~mm} \mathrm{Hg}$ and $10.3 \pm 3.1 \mathrm{~mm} \mathrm{Hg}$, respectively, while Meldrum et al. (12) have reported IAP values of $27 \pm 2.3$ and $14 \pm 4.6 \mathrm{mmHg}$, respectively. Daga and coworkers (13) have reported an overall 65\% incidence of IAH at admission, which is similar to our study. The incidence of IAH fell to just $8 \%$ after 24 hours of surgery, which was lower than in our study. Kidwai et al. (1) in their study have reported an overall IAH incidence of $32 \%$, while that in the sub-group of patients with perforation peritonitis was $66.32 \%$. In the IROI study, IAH was present in $34.0 \%$ of the critically ill patients on the day of ICU admission (14). The severity of intra-abdominal hypertension was as follows: grade I, 47.5\%; grade II, 36.6\%; grade III, 11.7\%; and grade IV, 4.2\%.

A large number of studies have demonstrated that raised IAP adversely affects various organ systems (15-17). This dysfunction is often reflected in the deterioration of prognostic scores such as APACHE II and SOFA score, which are widely used world over.

Mean APACHE II score at admission in our study was $7.55 \pm 4.96$ (range 0-21), and there was no correlation with the values of IAP. Mean SOFA score at admission, and post-operatively at 24 and 48 hours respectively were $2.25 \pm 1.65,2.82 \pm 2.98$ and 2.82 \pm 3.20. In our study, 24 hours post-operative SOFA score correlated with IAP measured after 48 hours of surgery and was significant ( $p$ value 0.021). Also, 48 hours post-operative SOFA score correlated significantly with both the IAP values measured post-operatively ( 24 and 48 hours, p value $0.002,<0.001$ respectively) (Table 3 ).

Median baseline APACHE II score reported by De-Waele and coworkers was 25.5 (20.0-31.8). The higher score was because the study included patients with established ACS who were to undergo decompressive laparotomy (DL). Median SOFA score before DL was 10 (7-12) which initially increased to 11 (8-13) at $24 \mathrm{~h}(\mathrm{p}=0.02)$, then reduced to 9 (5-13) on day $3(p=0.871)$ and 6 (4-11) on day $7(p=0.098)$ after DL. Their study confirmed the beneficial effect of timely DL on organ dysfunction (18).

In a study by Kulkarni et al., mean APACHE II score was 11.38 (range of 1-23). They concluded that APACHE-II score between 11 and 20 was a better predictor of risk of mortality in patients with perforation peritonitis (19). In the study by Pereira and colleagues, mean SOFA score on admission was $6.54 \pm 2.71$, while it was higher in patients with the diagnosis of ACS (8.42 \pm 1.27$)$ (20). The authors have concluded that SOFA score at admission higher than 7 correlated with IAH, with an accuracy of $68.8 \%$ $(p<0.03)$. Dorigatti et al. have concluded in their study that elevated IAP correlated with higher central venous pressure (CVP) $(p=0.0421)$; positive end-expiratory pressure (PEEP) ( $p=$ $0.0056)$; elevated airway pressure ( $p=0.0015)$; accumulated fluid balance $(p=0.0273)$, and elevated SOFA ( $p=0.0393)$ in septic patients (21).

Mortality rate in our study was $17.5 \%$. A similar mortality rate (16.7\%) has been reported in another study (22). The mortality rate reported by Meena et al. was $14.7 \%$ while Jhobta et al. (23) has reported mortality rate of 10\%.

In our study, among the various IAP values, statistically significant correlation with mortality was seen only with post-operative IAP measurement taken at 48 hours ( $p$ value 0.014). Kidwai and colleagues have reported that elevated IAP pre-operatively and post-operatively at 6 hours was found to independently predict the occurrence of death $(p<0.05)$ but not at 0,12 and 24 hours post-operatively ( $p>0.05$ ) (1). In the IROI study, the authors have concluded that the severity of intra-abdominal hypertension during the first 2 weeks of the ICU stay was identified as an independent predictor of 28- and 90-day mortality, whereas the presence of intra-abdominal hypertension on the day of ICU admission did not predict mortality (14). 
Prolonged ileus was seen in only $7.7 \%(n=3)$ patients. In these patients, its occurrence correlated significantly with all five IAP values, highest with IAP just before induction of GA ( $p$ value 0.006). Agrawal and colleagues have reported occurrence of prolonged ileus in $8 \%$ of patients but found no statistically significant correlation with IAP (24).

It has been postulated that poor healing and possible dehiscence of abdominal surgical wounds may result from reduced blood flow to the abdominal wall caused by increased IAP (25). Burst abdomen occurred in $22.5 \%(n=9)$ cases and there was no correlation with IAP. A similar incidence (20\%) has been reported in one Indian study (26). No significant association has been found between IAP at any point of time and occurrence of burst abdomen in the study by Khan et al. (27).

Among the 33 survivors, mean duration of hospital stay was $13.45 \pm 10.28$ days (median 9 days). There was no correlation with IAP measurements. Mean post-operative duration of hospital stay was $7.6 \pm 4.2$ days in the study by Gupta et al. Another study reported a prolonged hospital stay in $47 \%$ of the cases (13). Al-Bahrani et al. found have that a high admission IAP is associated with prolonged intensive care stay (28).

Intra-abdominal pressure undoubtedly influences patient outcome, contributing to both mortality as well as morbidity, although to a varying extent. While some outcomes may be significantly affected, others tend to be less conducive to the changes in IAP.

The study has a few limitations. First, the sample size was relatively small as the study was conducted in only one surgery unit of the institute. Second, the duration of symptoms was not taken into consideration. Also, some patients were operated within a few hours of admission, while some others needed longer time for optimization prior to be taken up for surgery. This difference in time lag could not be accounted for in the study. Third, there is a possibility of human observational bias as the IAP was read on a saline manometer instead of a digital pressure transducer. Fourth, the first post-operative measurement of IAP was taken only after 24 hours of surgery even though some studies have shown that post-operative IAP measured at much earlier times (4-6 hours) predicts outcomes. Lastly, occurrence of burst abdomen is multi-factorial and IAP is only one of the putative factors. The confounding effect of other factors could not be eliminated.

\section{CONCLUSION}

Rise in IAP correlates with deterioration of SOFA score and also with the occurrence of prolonged ileus. It is also a predictor of mortality. IAP measured post-operatively (24 and 48 hours) had a better correlation with these outcomes than the value measured at admission. No statistically significant correlation could be found with the occurrence of burst abdomen, as well as duration of hospital stay. Further understanding of these relationships warrants studies with a larger sample size. Thus, IAP measurement is a simple inexpensive bedside tool which can be regularly used in clinical practice to understand its role in the outcomes of these patients, and for their better management.

Ethics Committee Approval: This was obtained from Maulana Azad Medical College and Associated Hospital Instutional Ethics Commitee. (Date: 21.10.2018, Decision no: 17/IEC/MAMC/2018/15)

Peer-review: Externally peer-reviewed.

Author Contributions: Concept -L.B., P.L., P.K.N.; Design - L.B., P.K.N., A.M.; Supervision -P.L., A.M., P.K.N., L.B.; Data Collection and/or Processing - L.B., P.K.N., M.Y.B.; Analysis and/or Interpretation - L.B. P.K.N., P.L., A.M.; Literature Search - L.B. P.K.N., P.L., A.M.; Writing Manuscript - P.K.N., L.B., H.M., Critical Reviews - All of authors.

Conflict of Interest: The authors have no conflicts of interest to declare.

Financial Disclosure: The authors declared that this study has received no financial support.

\section{REFERENCES}

1. Kidwai R, Baral RK, Sharma A. Analysis of intra-abdominal pressure in obstructive and perforative lesions of gastro-intestinal tract. J Nep Med Col 2018; 16(2): 31-4. [CrossRef]

2. Sugrue $M$, Buhkari Y. Intra-abdominal pressure and abdominal compartment syndrome in acute general surgery. World I Surg 2009; 33(6): 1123-7. [CrossRef]

3. Reintam A, Parm P, Kitus R, Kern H, Starkopf J. Primary and secondary intra-abdominal hypertension - different impact on ICU outcome. Intensive Care Med 2008; 34: 1624-31. [CrossRef]

4. Bains L. Lal P, Mishra A, Gupta A, Gautam KK, Kaur D. Abdoinal compartment syndrome: a comprehensive pathophysiological review. MAMC J Med Sci 2019; 5: 47-56. [CrossRef]

5. Vincent JL, Moreno R, Takala J, Willatts S, De Mendonca A, Bruining $H$ et al. The SOFA (Sepsis-related Organ Failure Assessment) score to describe organ dysfunction/failure. Intensive Care Med 1996; 22(7): 707-10. [CrossRef]

6. Knaus WA, Draper EA, Wagner DP, Zimmerman JE. APACHE II. Critical Care Med 1985; 13(10): 818-9. [CrossRef]

7. Cheatham ML. Abdominal compartment syndrome: Pathophysiology and definitions. Scand J Trauma Resusc Emerg Med 2009; 17: 10. [CrossRef]

8. Malbrain MLNG, Cheatham ML, Kirkpatrick A, Sugrue M, Parr M, De Waele $J$ et al. Results from the conference of experts on intra-abdominal hypertension and abdominal compartment syndrome. Part I: Definitions. Intensive Care Med 2006; 32: 1722-32. [CrossRef]

9. Sharma K, Kumar M, Batra UB. Anesthetic management for patients with perforation peritonitis. J Anaesthesio/ClinPharmacol 2013; 29(4): 445-53. [CrossRef]

10. Cheatham ML. Nonoperative management of intraabdominal hypertension and abdominal compartment syndrome. World J Surg 2009; 33: 1116-22. [CrossRef]

11. Sugrue M, Buist MD, Hourihan F, Deane S, Bauman A, Hillman K. Prospective study of intra-abdominal hypertension and renal function after laparotomy. Br J Surg 1995; 82: 235-8. [CrossRef]

12. Meldrum DR, Moore FA, Moore EE. Prospective characterization and selective management of the abdominal compartment syndrome. Am J Surg 1997; 174:667-73. [CrossRef] 
13. Daga S, Yerrapragada S, Chowdary AK, Satyanarayana G. Analyzing intra-abdominal pressures and outcomes in patients undergoing laparotomy. Int Surg J 2017 Jan; 4(1): 111-6. [CrossRef]

14. Blaser R, Regli A, De Keulenaer B, Kimball EJ, Starkopf L, Davis WA et al. Incidence, risk factors, and outcomes of intra- abdominal hypertension in critically ill patients- a prospective multicenter study (IROI Study). Crit Care Med 2019; 47(4): 535-42. [CrossRef]

15. Mahran GS, Abbas MS. Compartment syndrome: A cornerstone in critical care management. J Anaesthesiol Crit Care 2017; 1:2. [CrossRef]

16. Meldrum DR, Moore FA, Moore EE, Franciose RJ, Sauaia A, Burch JM. Prospective characterization and selective management of the abdominal compartment syndrome. Am J Surg 1997; 174:667-72. [CrossRef]

17. De Waele JJ, De Laet I, Kirkpatrick AW, Hoste E Intraabdominal hypertension and abdominal compartment syndrome. Am J Kidney Dis 2011; 57: 159-69. [CrossRef]

18. De Waele JJ, Kimball E, Malbrain M, Nesbitt I, Cohen J, Kaloiani V et al. Decompressive laparotomy for abdominal compartment syndrome. BJS 2016; 103: 709-15. [CrossRef]

19. Kulkarni SV, Naik AS, Subramanian N. APACHE-Il scoring system in perforative peritonitis. The American Journal of Surgery 2007; 194: 549-52. [CrossRef]

20. Pereira BM, Dorigatti AE, Melek MZ, Santos JLD, Ferreira M, Calderan TRA at al. Septic shock patients admitted to the intensive care unit with higher SOFA score tend to have higher incidence of abdominal compartment syndrome - a preliminary analysis. Anaesthesiol Intensive Ther 2019; 51: 4. [CrossRef]
21. Dorigatti $A E$, Pereira BM, Melek MZ, dos Santos JL, Teramoto FD, Fraga GP. Cinical warning signs for IAH in septic shock. Anaesthesiol Intensive Ther 2019; 51: 3. [CrossRef]

22. Memon AA, Siddiqui FG, Abro AH, Agha AH, Lubna S, Memon AS. An audit of secondary peritonitis at a tertiary care university hospital of Sindh, Pakistan. World J Emerg Surg 2012; 7: 6. [CrossRef]

23. Jhobta RS, Attri AK, Kaushik R, Sharma R, Jhobta A. Spectrum of perforation peritonitis in India - Review of 504 consecutive cases. World J EmergSurg 2006; 1: 26. [CrossRef]

24. Agrawal S, Chaudhary T, Sahu SK. Correlation of intra-abdominal pressure with the outcome of perforation peritonitis. Int Surg J 2017 May; 4(5): 1584-7. [CrossRef]

25. Lee RK. Intra-abdominal hypertension and abdominal compartment syndrome: A comprehensive overview. Crit Care Nurse 2012; 32: 19-31. [CrossRef]

26. Gupta N, Gupta S. Clinical significance and correlation of intra-abdominal pressure with the outcome of perforation peritonitis. Int J Med Biomed Stud; 3(5): 245-7. [CrossRef]

27. Khan S, Verma AK, Ahmad SM, Ahmad R. Analyzing intra-abdominal pressures and outcomes in patients undergoing emergency laparotomy. J Emerg Trauma Shock 2010; 3: 318-25. [CrossRef]

28. Al-Bahrani AZ, Abid GH, Holt A, McCloy RF, Benson J, Eddleston J et al. Clinical relevance of intra-abdominal hypertension in patients with severe acute pancreatitis. Pancreas. 2008; 36: 39-43. [CrossRef]

\section{ORIJINAL ÇALIŞMA-ÖZET}

Turk J Surg 2021; 37 (3): 253-259

\section{Perforasyon peritonitinin sonuçlarında karın içi basıncın rolü: İleriye dönük bir gözlemsel çalışma}

Pritesh Kumar N, Lovenish Bains, Pawan Lal, Anurag Mishra, Mohd Yasir Beg, Haraesh Maranna

Maulana Azad Tıp Üniversitesi, Cerrahi Anabilim Dalı, Yeni Delhi, Hindistan

\section{ÖZET}

Giriş ve Amaç: Karın içi basıncın (IAP), morbidite ve mortaliteye etkisindeki rolünü araştıran çeşitli çalışmalarda farklı korelasyon dereceleri göstermiştir. Bu konuda perforasyon peritoniti hastalarında, özellikle Hint yarımadasındaki çalışmalara dayanan literatür eksikliği vardır.

Gereç ve Yöntem: Bu araştırma, laparotomi yapılan perforasyon peritonitli 40 hastayı içeren prospektif bir gözlemsel çalışmadır. IAP, WSACS (World Society of Abdominal Compartment Syndrome) yönergelerine göre ölçülmüştür. Bu itibarla hastalarda APACHE II (Acute Physiology and Chronic Health Evaluation- II) ve SOFA skorları (Sequential Organ Failure Assessment) hesaplandı. Uzamış ileus, evantrasyon, hastanede kalış süresi, 30 günlük mortalite ile ilgili veriler toplandı ve IAP ile korelasyon gösterecek şekilde istatistiksel olarak analiz edildi.

Bulgular: Başvuru sırasında ortalama IAP 13,37 mmHg ve IAH insidansı $\% 65$ idi. Ameliyat sonrası 24. saat ve 48. saatte IAH \%17,9 ve \%7,6'da görüldü. Uzamış ileus ve evantrasyon insidansı sırasıyla $\% 7,7$ ve $\% 22,5$ idi. Ölüm oranı $\% 17,5$ idi. Ortalama hastanede kalış süresi 13,45 gündü. Ameliyat sonrası IAP mortalite ( $p$ : 0,014) ve ameliyat sonrası SOFA skoru $(p<0,05)$ ile korele idi. Uzamış ileus oluşumu ile de istatistiksel olarak anlamlı korelasyon görüldü ( $p: 0,006$ ). IAP, APACHE II skoru, patlama karnının oluşumu ve hastanede kalış süresi ile anlamlı bir korelasyon göstermedi.

Sonuç: IAP'deki artış, SOFA skorunun bozulması ve ayrıca uzamış ileus oluşumu ile ilişkilidir. IAP ayrıca mortalitenin bir öngörücüsüdür. Postoperatif olarak ölçülen IAP (24 ve 48 saat), bu sonuçlarla, başvuru sırasında ölçülen değerden daha iyi bir korelasyona sahipti. IAP'nin evantrasyon oluşumu ve hastanede kalış süresi ile istatistiksel olarak anlamlı bir korelasyonu bulunamamıştır. Bu daha geniş bir popülasyonla yapılacak daha ileri çalışmaları desteklemektedir.

Anahtar Kelimeler: Perforasyon peritoniti, karın içi basınç, karın içi hipertansiyon

DOi: $10.47717 /$ turkjsurg.2021.4945 
260 Correlation between intra-abdominal pressure and the outcomes of perforation peritonitis 